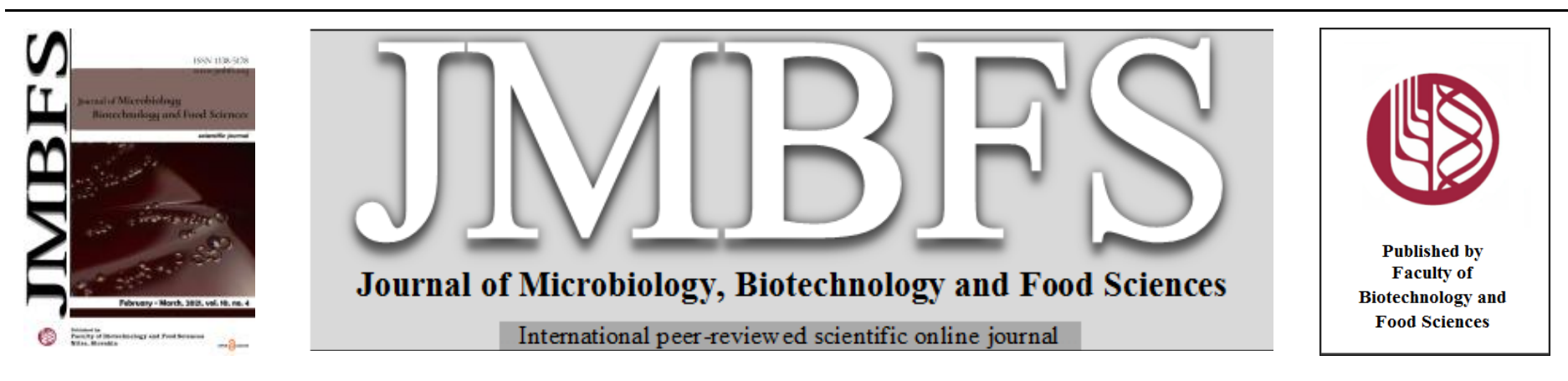

\title{
EXTRACELLULAR BIOSYNTHESIS, OPTIMIZATION, CHARACTERIZATION AND ANTIMICROBIAL POTENTIAL OF ESCHERICHIA COLI D8 SILVER NANOPARTICLES
}

\author{
Mahmoud M. Nour El-Dein ${ }^{1}$,Zakaria A. M. Baka ${ }^{1}$,Mohamed I. Abou-Dobaral ${ }^{l}$,Ahmed K.A. El-Sayed ${ }^{l}$, Mohamed M. El-Zahed ${ }^{1}$ \\ Address(es): PhD student Mohamed El-Zahed, \\ ${ }^{1}$ Damietta University, Faculty of Science, Department of Botany and Microbiology, New Damietta, Egypt.
}

*Corresponding author: mohamed.marzouq90@gmail.com

doi: 10.15414/jmbfs.2021.10.4.648-656

\section{ARTICLE INFO}

Received 19.1.2020

Revised 27. 10. 2020

Accepted 29. 10. 2020

Published 1. 2. 2021

Regular article

OPEN $\partial_{\text {Access }}$

\begin{abstract}
This study highlights the optimization of extracellular biosynthesis and antimicrobial efficiency of silver nanoparticles (AgNPs) using the crude metabolite of Escherichia coli D8 (MF06257) strain. The bacterial strain had been isolated from a sewage water stream located in Damietta City, Egypt. The optimum conditions for AgNPs production were at temperature $35^{\circ} \mathrm{C}$, $\mathrm{pH} 7$ and $1.5 \mathrm{mM}$ silver nitrate. The AgNPs biosynthesis was detected in culture filtrate within 1-2 minutes at room temperature $\left(25 \pm 2^{\circ} \mathrm{C}\right)$ and sunlight. The characterization of AgNPs was studied by UV-Vis spectroscopy (maximum absorbance at $429 \mathrm{~nm}$ ), X-ray diffraction (XRD) pattern (crystal planes were 110, 111, 200, 211, 220, and 311), transmission electron microscopy (TEM) (AgNPs were spherical in shape ranging from 6 to $17 \mathrm{~nm}$ ), Fourier transform-infrared (FTIR) spectroscopy (the bands of symmetric and asymmetric amines were assigned at 3421.1 and $2962.13 \mathrm{~cm}^{-1}$, the stretching vibration band of aromatic and aliphatic (C-N) exist at 1392.35 and $1122.37 \mathrm{~cm}^{-1}$ bands), Zeta potential analyser (AgNPs had a negative charge value; $-33.6 \mathrm{mV}$ ) and size distribution by volume (the presence of capping agent enveloping the AgNPs with a mean size of 136.0-294.3 nm). Nitrate reductase (NR) was assayed as an important partner in the optimized production (the rate of NR reached to $2.18 \mathrm{U} / \mathrm{ml}$ ). The study demonstrated that AgNPs are potent inhibitors of Staphylococcus aureus, E. coli, Pseudomonas aeruginosa, Alternaria alternata, Fusarium oxysporum and Aspergillus flavus. The antimicrobial activity of AgNPs was studied by TEM. TEM micrographs showed an inhibition of $S$. aureus cell multiplication. In case of $F$. oxysporum, a reduction in the size of treated cells, formation of a mucilage matrix connecting the hyphal cells together, the appearance of a big vacuole, lipid droplets an a severe leakage of cytoplasmic contents were detected. AgNPs exhibited MIC values of $6.25 \mu \mathrm{g} / \mathrm{ml}$ and 50 $\mu \mathrm{g} / \mathrm{ml}$ against $S$. aureus and Candida albicans, respectively. In addition, AgNPs showed synergy effects by their combination with fluconazole that increased fold areas especially against A. niger, A. flavus and F. oxysporum.
\end{abstract}

\section{INTRODUCTION}

Among metallic nanoparticles, silver nanoparticles (AgNPs) have numerous applications in the field of nanobiotechnology due to their unique antimicrobial efficiency as growth inhibitors, killing agents or antibiotic carriers (Hamidi $\boldsymbol{e}$ al., 2019). AgNPs have widely attracted attention for the food, cosmetics and biomedical applications (Sondi and Salopek-Sondi, 2004).

In the last few years, different chemical and physical methods had been included in AgNPs synthesis. These incorporated methods produced contaminated, toxic AgNPs in low yields. So, scientific researchers went to the biological synthesis of AgNPs using microorganisms (Wang et al., 2019). Through microbial biosynthesis, numerous scientists used bacterial strains in AgNPs biosynthesis due to their rapid growth rate and highly efficient enzymatic system (Galvez et al., 2019). The use of bacterial crude metabolites was embedded as reducing agents of silver ions into safe and ecofriendly AgNPs that called extracellular biosynthesis (De Souza et al., 2019). The extracellular production is more prioritized than the intracellular which requires extraction and purification of AgNPs from the microbial growth. In addition, the extracellular production was confirmed to include high amounts of proteins which acted as capping agents (Annamalai and Nallamuthu, 2016). One of the mechanistic aspects for AgNPs biosynthesis is the secreted enzymes by bacteria that act as reducing agents for silver ions (Quinteros et al., 2016). The shape and size of the biosynthesized nanoparticles (NPs) could be handled throughout controlling the production parameters such as concentration of metal ions, temperature, incubation period, $\mathrm{pH}$ and effect of solar irradiation (Sumitha et al., 2019).

AgNPs have a strong bactericidal effect against a broad spectrum of bacteria such as Pseudomonas sp., Acinetobacter sp., Escherichia sp., Vibrio sp. and Salmonella sp. (Paul and Londhe, 2019). Furthermore, the biosynthesized AgNPs showed significance antifungal potential against Aspergillus flavus, A. nomius and A. parasiticus, Alternaria alternata, Fusarium sp., Candida tropicalis and C. albicans was reported (Bocate et al., 2019). This makes the AgNPs a potential candidate as a new generation of antifungal agents.

The present work aimed to obtain a potent bioreductant bacterium possessing the ability to synthesize AgNPs extracellularly with efficient antimicrobial activity.

\section{MATERIAL AND METHODS}

Chemicals

Culture media was purchased from Difco Laboratories, Detroit, Mich. Chemicals were purchased from Oxoid Ltd., England. Silver nitrate was purchased from Panreac Quimica S.L.U, Barcelona, Spain. Fluconazole (Diflucan) was purchased from Pfizer Inc., New York, NY.

\section{Microbial strains}

The E. coli D8 strain was isolated from a sewage water stream located at Damietta City, Egypt). It was identified classically according to Bergey's Manual of Systematic Bacteriology (Imhoff, 2005). The 16S rRNA gene sequence was also performed in order to confirm its identification and deposited in the database under accession number MF06257.

The bacterial and fungal strains used for the antimicrobial activity were kindly provided by the culture collection of Microbiology Laboratory, Faculty of Science, Damietta University, Egypt (Table 1) 
Table 1 The bacterial and fungal strains used for the antimicrobial activity.

\begin{tabular}{ll} 
Microorganism & Strains \\
& Bacillus cereus ATCC6633 \\
& Staphylococcus aureus ATCC25923 \\
Bacteria & Escherichia coli ATCC25922 \\
& Klebsiella pneumoniae ATCC33495 \\
& Pseudomonas aeruginosa ATCC27853 \\
\hline Yeast & Candida albicans ATCC10231 \\
\hline & Aspergillus niger van Tiegh \\
& A. flavus Link ex Fries group \\
Fungi & A. fumigatus Fresenius \\
& Alternaria alternata Fr. Keissler \\
& Fusarium oxysporum f. sp. lycopersici Fol4287
\end{tabular}

\section{Experimental procedure}

\section{Extracellular biosynthesis of silver nanoparticles}

Escherichia coli D8 MF06257 was grown in nutrient broth (NB) medium and incubated at $37^{\circ} \mathrm{C}$ for 48 hours at $150 \mathrm{rpm}$. After an incubation period, the bacterial crude metabolites were collected throughout centrifuging at $5000 \mathrm{rpm}$ for 20 minutes aseptically. Two hundred $\mu \mathrm{L}$ of bacterial crude metabolites were added to $20 \mathrm{ml}$ of an autoclaved aqueous solution of $1 \mathrm{mM}$ silver nitrate $(1 \% \mathrm{v} / \mathrm{v})$ in triplicates. The negative control was prepared by adding $200 \mu \mathrm{L}$ of the NB medium into $20 \mathrm{ml}$ of the silver nitrate solution. All samples were incubated at $150 \mathrm{rpm}$ for 5 days at $37^{\circ} \mathrm{C}$ in dark. After incubation, the appearance of brown colour was observed and measured spectrophotometrically as an indication of the production of AgNPs (Shahverdi et al., 2007). The reaction mixtures were measured in the range of 370 to $750 \mathrm{~nm}$ at a resolution of $1 \mathrm{~nm}$ using a UV-Vis spectrophotometer (Beckman DU-40) against control test tube as the blank (silver nitrate solution and nutrient broth medium) (Krishnaraj et al., 2012).

\section{Optimization of extracellular biosynthesized silver nanoparticles}

The optimizing process included different parameters such as differen concentrations of silver nitrate $(0.5,1,1.5,2,2.5,3,3.5$ and $4 \mathrm{mM})$, temperatures $\left(25-45^{\circ} \mathrm{C}\right)$, $\mathrm{pH}$ values $(5-10)$ and different incubation periods $(12,24,36,48,60$, 72 and 84 hours) (Krishnaraj et al., 2012). In addition, the synthesis of AgNPs was tested in the presence of solar irradiation at different periods of time $(1,2,3$, 4, 5 and $6 \mathrm{~min}$ ) (Sumitha et al., 2019). All samples were measured spectrophotometrically in the range of 370 to $750 \mathrm{~nm}$ in order to detect the AgNPs biosynthesis.

\section{Characterization of biosynthesized silver nanoparticles}

The X-ray diffraction (XRD) pattern of the AgNPs was recorded at $2 \theta$ values between $10^{\circ}$ and $80^{\circ}$ using a $\mathrm{Cu} \mathrm{X}$-ray tube at $40 \mathrm{kV}$ and $30 \mathrm{~mA}$ with the X-ray diffractometer (model LabX XRD-6000, Shimadzu, Japan) at Nanotechnology Center, Kafrelsheikh University, Egypt).

The following characterizations of AgNPs were performed at TEM Unit at Mansoura University, Egypt. The shape and size of the optimized AgNPs were examined using TEM, a drop coating of nanocolloidal solution into carboncoated copper grid (Type G 200, $3.05 \mu \mathrm{M}$ diameter, TAAP, USA) was prepared and kept overnight under vacuum desiccation before loading them onto a specimen holder. TEM micrographs of samples were taken using TEM instrument operated at an accelerating voltage of $200 \mathrm{kv}$ using TEM (JEOL, JEM-2100, Japan). Size distribution by volume and charge of AgNPs were measured by Zeta Potential Analyser (Malvern Zetasizer Nano-ZS90, Malvern, UK). A colloidal solution was used in this instrument by withdrawing $1 \mathrm{ml}$ of solution into the instrumental cuvette for measuring (Ruud et al., 1976; Hanaor et al., 2012). The AgNPs capping agents were analysed by Fourier Transform Infrared Spectroscopy (FTIR) spectrum. It was done for the freeze-dried powder of AgNPs using FT/IR-4100 type $\mathrm{A}$ in the diffuse reflectance mode at a resolution of $16 \mathrm{~cm}^{-1}$ at the range of $400-4000 \mathrm{~cm}^{-1}$ (Siddique et al., 2013).

\section{Nitrate reductase assay}

The assay of nitrate reductase (NR) was performed according to Harley (1993) depending on the reduction of nitrate into nitrite by nitrate reductase (NR). The NR activity was calculated pertain the amount of the produced nitrite during 60 minutes using $10 \mathrm{ml}$ of sample. Production of one $\mu \mathrm{mol}$ nitrite $/ \mathrm{h} / \mathrm{ml}$ was defined as one unit of NR activity (U/ml).
Antimicrobial activities of silver nanoparticles

\section{Agar well diffusion method}

Agar well diffusion assay was performed according to the guidelines of the Clinical and Laboratory Standards Institute (Clinical and Laboratory Standards, 2006). The antimicrobial activities of the optimized biosynthesized AgNPs were investigated at concentrations of 50,100, and $150 \mu \mathrm{g} / \mathrm{ml}$ in dimethyl sulfoxide (DMSO). The antibacterial potential was tested against Gram-positive bacteria (Bacillus cereus ATCC6633 and S. aureus ATCC25923), Gram-negative bacteria (E. coli ATCC25922, Pseudomonas aeruginosa ATCC27853 and Klebsiella pneumoniae ATCC33495) on the Mueller-Hinton agar (MHA) plates The antifungal potential was performed against fungal species (Aspergillus flavus Link ex Fries group, A. fumigatus Fresenius, A. niger van Tiegh, Fusarium oxysporum f. sp. lycopersici Fol4287 and A. alternata Fr. Keissler) with DOX agar plates in addition to $C$. albicans ATCC10231 using Bacto casitone agar plates. $100 \mu \mathrm{L}$ culture of each strain $(0.5$ McFarland standard $(1-2 \times 108$ $\mathrm{CFU} / \mathrm{ml})$ ) was inoculated separately into the agar plates. Wells $(8 \mathrm{~mm})$ were inoculated with $50 \mu \mathrm{l}$ of AgNPs colloids. Penicillin G and Fluconazole were used as antibacterial and antifungal positive control standard, respectively. Plates were incubated at $37^{\circ} \mathrm{C}$ or $28^{\circ} \mathrm{C}$ for bacteria and fungi, respectively. After incubation, zones of inhibition (ZOI) were measured in terms of millimetres after 24 hours and 7 days for bacteria and fungi, respectively.

The synergistic effect of AgNPs combined with Penicillin G or Fluconazole was also determined against the pathogenic bacteria and fungi. $30 \mu \mathrm{g}$ Penicillin $\mathrm{G}$ or Fluconazole was loaded with $20 \mu \mathrm{l}(100 \mu \mathrm{g} / \mathrm{ml})$ of biosynthesized AgNPs colloid and tested by comparing to Penicillin G or Fluconazole alone $(100 \mu \mathrm{g} / \mathrm{ml})$.

The increase in the fold area was calculated the mean of ZOI of each antimicrobial agent alone (Penicillin G or Fluconazole) and combined with AgNPs using the equation $(B 2-A 2) / A 2$, where $\mathrm{A}$ and $\mathrm{B}$ were $\mathrm{ZOI}$ for antimicrobial agent alone and combined with AgNPs, respectively (Birla $\boldsymbol{e t}$ al. 2009). All the experiments were performed in triplicate.

\section{Minimal inhibitory concentration (MIC)}

The MIC values for S. aureus ATCC25923 and C. albicans ATCC10231 were measured using broth microdilution method according to the guidelines of the National Committee for Clinical Laboratory Standards (NCCLS) (Clinical Laboratory Standards, 2008; 2017). A 0.5 McFarland standard of S. aureus ATCC25923 and C. albicans ATCC10231 were grown on Mueller-Hinton broth (MHB) and RPMI broth medium, respectively. Serial solutions of AgNPs, Penicillin $\mathrm{G}$ and Fluconazole $(6.25-125 \mu \mathrm{g} / \mathrm{ml}$ in water) were tested. Mixtures were incubated at $37{ }^{\circ} \mathrm{C}$ and $35^{\circ} \mathrm{C}$ for $S$. aureus ATCC25923 and C. albicans ATCC10231, respectively. After $48 \mathrm{hr}$, the growth turbidity was measured using a spectrophotometer against the growth control at $630 \mathrm{~nm}$ wavelength to determine n-values for each antimicrobial agent.

Transmission Electron Microscopy (TEM) of nanosilver treated microorganisms

The exponential-phase cultures of $S$. aureus ATCC25923 and $F$. oxysporum f. sp lycopersici Fol4287 were subjected to silver nanocolloids $(6.25,50,100$ and 150 $\mu \mathrm{g} / \mathrm{ml}$ and 50,100 and $150 \mu \mathrm{g} / \mathrm{ml}$, respectively) for 2 hours at $37^{\circ} \mathrm{C}$ and $30^{\circ} \mathrm{C}$, respectively. Normal bacteria and fungi were included as controls. The cell cultures were centrifuged at $5000 \mathrm{rpm}$ for 20 minutes, and then washed 3 times with distilled water. Fixative solution $(2.5 \%$ glutaraldehyde in $0.1 \mathrm{M}$ cacodylate buffer at $\mathrm{pH} 7$ ) was added and left for 20 minutes at room temperature. The fixative was removed and then $0.1 \mathrm{M}$ buffer was added for washing and postfixed with osmium tetroxide ( $2 \%$, in the same buffer) for 90 minutes. The fixed cells were dehydrated using graded series of ethanol. The dehydrated cells were embedded in Epon-Araldite $(1: 1)$ mixture for 1 hour that polymerized at $65^{\circ} \mathrm{C}$ for 24 hours. The cells were cross section using an ultra-microtome $(50 \mu \mathrm{m})$, doublestained with uranyl acetate and lead citrate and exposed to observation on carboncoated copper grids (Type G 200, $3.05 \mu \mathrm{M}$ diameter, TAAP, U.S.A.) using TEM (JEOL JEM-2100, Japan)

\section{Statistical analysis}

The data were statistically analyzed using software system SPSS version 18. All values in the experiments were expressed as the mean \pm standard deviation (SD) and were analyzed with one-way Analysis of Variance (ANOVA). The significant level was set at $p<0.05$.

\section{RESULTS}

\section{Optimization of biosynthesized AgNPs}

Escherichia coli D8 MF06257 biosynthesized AgNPs within 72 hours in dark conditions. The production of AgNPs was demonstrated by the peak at $429 \mathrm{~nm}$ in the UV-Vis spectra. Using $1 \%$ of bacterial supernatants and $1.5 \mathrm{mM}$ 
concentration greatly enabled AgNPs synthesis (Figure 1a). According to $\mathrm{pH}$ value, the brown colour appeared at $\mathrm{pH}$ (5-6) and its intensity was increased with the increase in $\mathrm{pH}$ value (Figure 1b). Stable and monodispersed AgNPs were synthesized at $\mathrm{pH} 7$. It was found that $350 \mathrm{C}$ was the optimal temperature for AgNPs synthesis (Figure 1c).

The brown colour appeared within 72 hours (Figure 1d) during incubation in dark conditions while biosynthesis occurred throughout a minute in case of the presence of solar irradiation (Figure 1e).
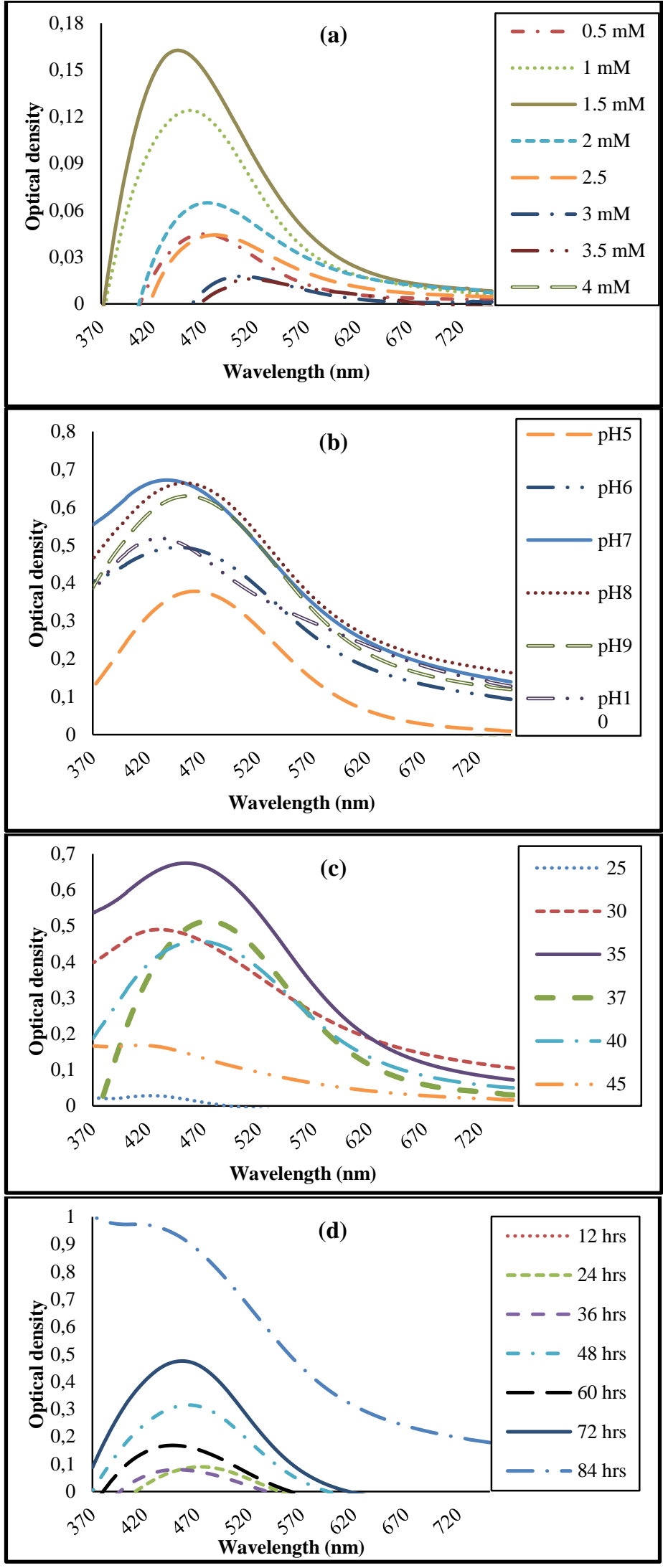

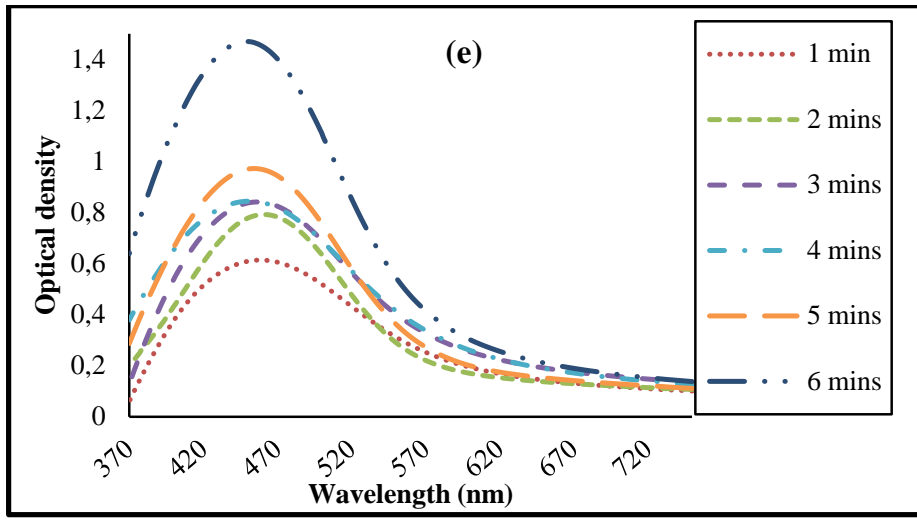

Figure 1 Optimization of AgNPs using E. coli D8 MF062579. (a) Different concentrations (0.5-4 mM) of AgNO3. (b) Effect of $\mathrm{pH}$ value on AgNPs synthesis. (c) Effect of temperature. (d) Different incubation periods through nanosilver biosynthesis at dark conditions. (e) Effect of solar irradiation on nanosilver biosynthesis.

\section{Characterization of the biosynthesized AgNPs}

The XRD pattern for E. coli D8 (MF062579) crude metabolite and AgNPs were shown in Figure 2. It showed six characteristic peaks of AgNPs that appeared at $31.7^{\circ}, 37.6^{\circ}, 45.7^{\circ}, 57^{\circ}, 64.26^{\circ}$, and $77.4^{\circ}$, corresponding to respective crystal planes (110), (111), (200), (211), (220), and (311) (Galvez et al., 2019)
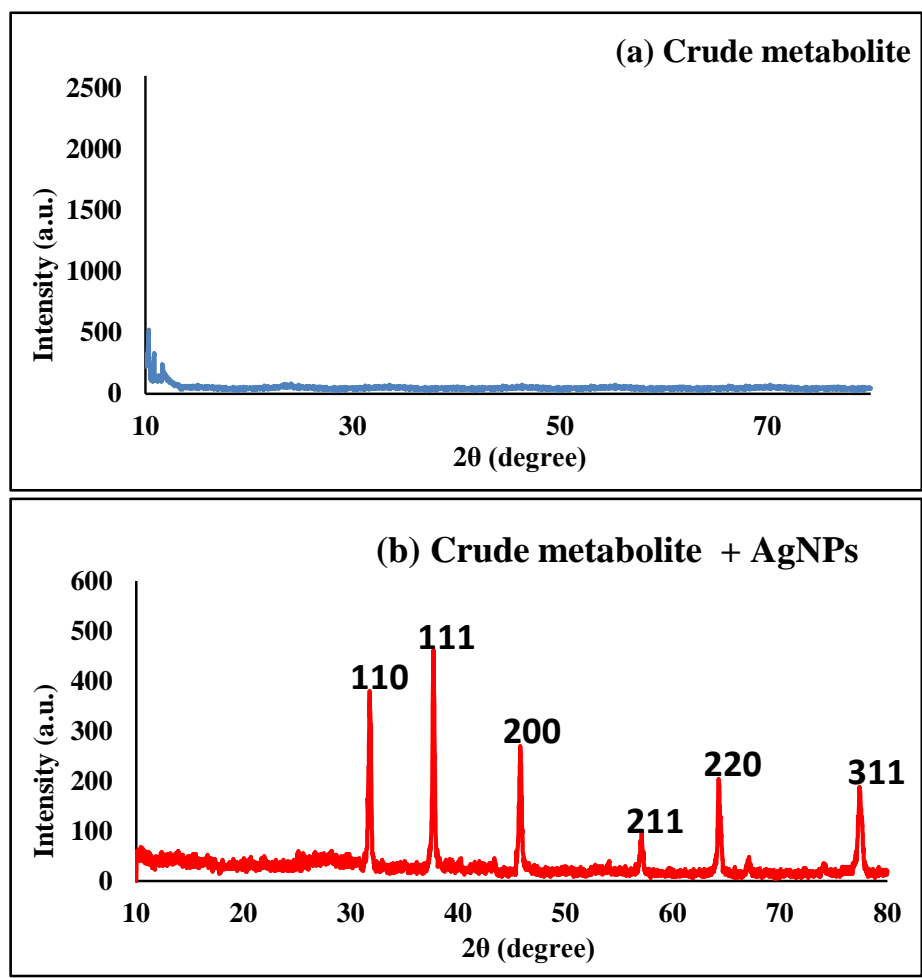

Figure 2 The XRD pattern of E. coli D8 (MF062579) crude metabolite; (a) and the produced AgNPs; (b).

TEM images (Figure 3) show the spherical shaped and well-dispersed AgNPs. The particle size distribution analysis in the present study showed a mean size of 6-17 $\mathrm{nm}$. 


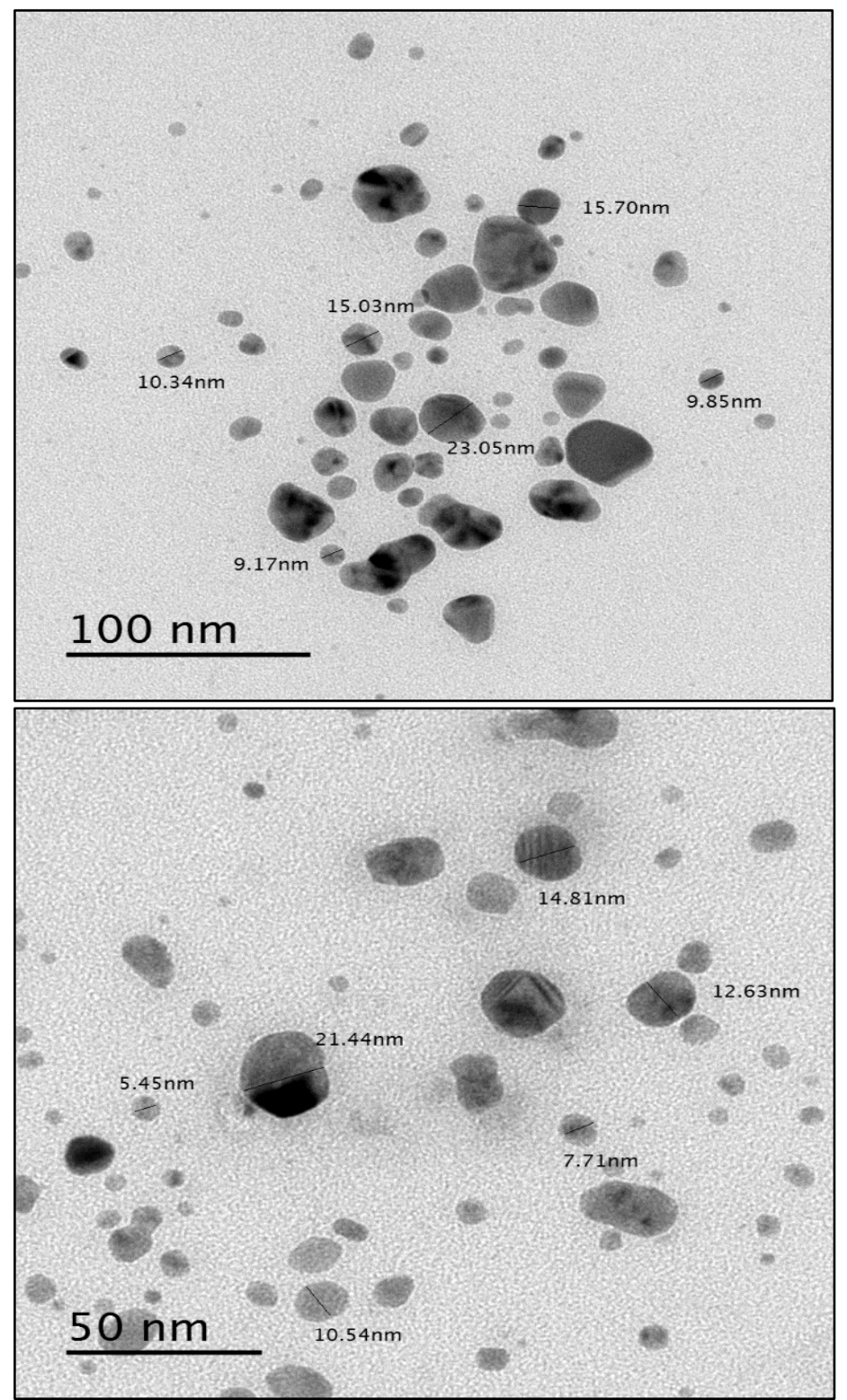

Figure 3 Transmission electron micrograph of produced AgNPs (scale bar $=100$ and $50 \mathrm{~nm}$ ).

The Zeta potential study established the negative charge (-33.6) of the AgNPs (Figure 4a) and the size distribution by volume showed the presence of a capping agent surrounded AgNPs having mean size of 136.0-294.3 nm (Figure 4b).
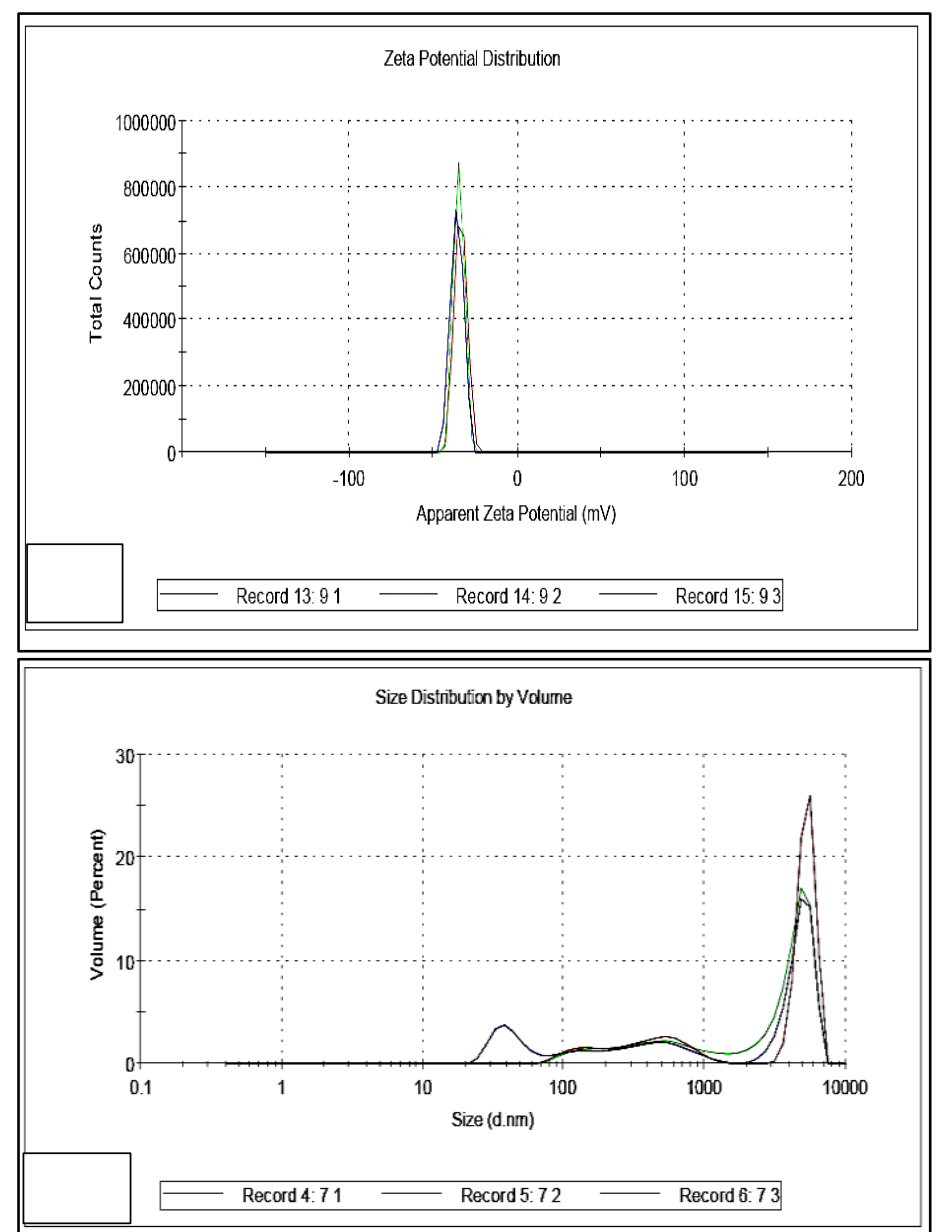

Figure 4 (a) Zeta potential measurement analysis of AgNPs. (b) Size distribution by volume.

Figure 5 illustrates the FTIR spectrum of E. coli D8 (MF062579) crude metabolite and AgNPs which confirmed the presence of proteins in the AgNPs biosynthesis. The stretch, primary and secondary amines vibrations bands were noted at $3421.1 \mathrm{~cm}^{-1}$ and $2962.13 \mathrm{~cm}^{-1}$, respectively. The stretching vibration of molecule appeared at $1658.48 \mathrm{~cm}^{-1}$ and $1596.77 \mathrm{~cm}^{-1}$ bands. The stretch C-N vibration of aromatic and aliphatic amines existed at $1392.35 \mathrm{~cm}^{-1}$ and 1122.37 $\mathrm{cm}^{-1}$ bands.

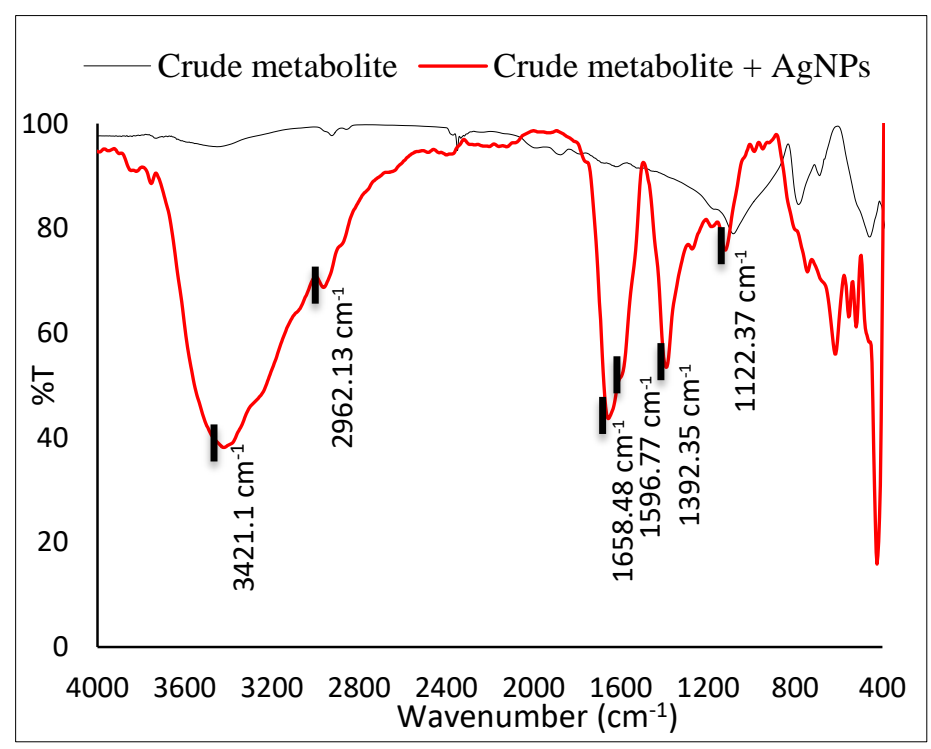

Figure 5 FTIR spectrum of E. coli D8 MF062579 crude metabolite with and without AgNPs.

\section{Nitrate reductase activity}

The activity of NR was measured and calculated in the E. coli D8 (MF062579) crude metabolite, at the rate of $2.18 \mathrm{U} / \mathrm{ml}$. 


\section{Antimicrobial Potential OF AgNPs}

\section{Agar well diffusion method}

The AgNPs synthesized by E. coli D8 (MF062579) isolate crude metabolite were centrifuged and dried using freeze dryer (SIM international, USA, FD8-8T) and tested against different pathogenic bacterial and fungal strains. There are significant differences in antimicrobial effects between the samples with $\mathrm{AgNps}$, Penicillin $\mathrm{G}$ and AgNPs \& Penicillin $\mathrm{G}$ treatment. Highly significant $(P<0.05)$ was observed between the microbial strains mainly $S$. aureus ATCC25923, E. coli ATCC25922, P. aeruginosa ATCC27853 (Table 2), A. alternata Fr Keissler, F. oxysporum f. sp. lycopersici Fol4287 and A. flavus Link ex Fries group (Table 3) and the diameter of inhibition zone.

Table 2 Antibacterial potential of AgNPs in comparison with benzylpenicillin (Penicillin G) as a standard drug in addition to the synergy action. (Highly significant $=* * p<0.05 ; n=3$ ).

\begin{tabular}{|c|c|c|c|c|c|c|}
\hline \multirow[b]{3}{*}{ Antibacterial agent } & \multirow{3}{*}{$\begin{array}{c}\text { Concentration, } \\
\mu \mathrm{g} / \mathrm{mL}\end{array}$} & \multicolumn{5}{|c|}{ Zone of inhibition (mm, mean) ${ }^{*}$} \\
\hline & & \multicolumn{2}{|c|}{ Gram-positive bacteria } & \multicolumn{3}{|c|}{ Gram-negative bacteria } \\
\hline & & $\begin{array}{l}\text { Bacillus cereus } \\
\text { ATCC6633 }\end{array}$ & $\begin{array}{c}\text { Staphylococcus } \\
\text { aureus } \\
\text { ATCC25923 }\end{array}$ & $\begin{array}{c}\text { Escherichia coli } \\
\text { ATCC25922 }\end{array}$ & $\begin{array}{c}\text { Pseudomonas } \\
\text { aeruginosa } \\
\text { ATCC27853 }\end{array}$ & $\begin{array}{c}\text { Klebsiella } \\
\text { pneumoniae } \\
\text { ATCC33495 }\end{array}$ \\
\hline & 50 & $12 \pm 0.03 * *$ & $20 \pm 0.14^{* *}$ & $18 \pm 0.14^{* *}$ & $17 \pm 0 * *$ & $14 \pm 0.14^{* *}$ \\
\hline \multirow[t]{3}{*}{ AgNPs } & 100 & $15 \pm 0 * *$ & $24 \pm 0 * *$ & $21 \pm 0 * *$ & $20 \pm 0.06 * *$ & $18 \pm 0.14^{* *}$ \\
\hline & 150 & $19 \pm 0.06 * *$ & $27 \pm 0.14^{* *}$ & $24 \pm 0.14^{* *}$ & $24 \pm 0 * *$ & $22 \pm 0 * *$ \\
\hline & 50 & $12 \pm 0.03 * *$ & $10 \pm 0 * *$ & $36 \pm 0.06 * *$ & $11 \pm 0.06 * *$ & -ve \\
\hline \multirow[t]{3}{*}{ Penicillin G } & 100 & $14 \pm 0 * *$ & $12 \pm 0.03 * *$ & $38 \pm 0 * *$ & $14 \pm 0 * *$ & -ve \\
\hline & 150 & $16 \pm 0 * *$ & $15 \pm 0.14^{* *}$ & $40 \pm 0 * *$ & $21 \pm 0.03^{* *}$ & -ve \\
\hline & 50 & $13 \pm 0.03^{* *}$ & $18 \pm 0 * *$ & $19 \pm 0.06^{* *}$ & $18 \pm 0.03 * *$ & $13 \pm 0 * *$ \\
\hline \multirow[t]{2}{*}{ AgNPs \& Penicillin G } & 100 & $15 \pm 0 * *$ & $21 \pm 0 * *$ & $23 \pm 0 * *$ & $20 \pm 0 * *$ & $18 \pm 0 * *$ \\
\hline & 150 & $17 \pm 0.03^{* *}$ & $25 \pm 0.14^{* *}$ & $27 \pm 0 * *$ & $25 \pm 0 * *$ & $21 \pm 0 * *$ \\
\hline
\end{tabular}

*Mean surface area of the inhibition zone was calculated for each from the mean diameter \pm SD.

Table 3 Antifungal potential of AgNPs in comparison with Fluconazole as a standard drug in addition to the synergy action

\begin{tabular}{|c|c|c|c|c|c|c|c|c|}
\hline \multirow{2}{*}{\multicolumn{2}{|c|}{ Antifungal agent }} & \multirow[b]{2}{*}{$\begin{array}{c}\text { Concentration, } \\
\mu \mathrm{g} / \mathrm{mL}\end{array}$} & \multicolumn{6}{|c|}{ Zone of inhibition (mm, mean) * } \\
\hline & & & $\begin{array}{c}\text { Aspergillus } \\
\text { niger van } \\
\text { Tiegh }\end{array}$ & $\begin{array}{c}\text { A. flavus } \\
\text { Link ex Fries } \\
\text { group }\end{array}$ & $\begin{array}{c}\text { A. } \\
\text { fumigatus } \\
\text { Fresenius }\end{array}$ & $\begin{array}{l}\text { Alternaria } \\
\text { alternata } \\
\text { Fr. Keissler }\end{array}$ & $\begin{array}{c}\text { Fusarium } \\
\text { oxysporum f. sp. } \\
\text { lycopersici } \\
\text { Fol4287 }\end{array}$ & $\begin{array}{c}\text { Candida } \\
\text { albicans } \\
\text { ATCC10231 }\end{array}$ \\
\hline \multirow{3}{*}{\multicolumn{2}{|c|}{ AgNPs }} & 50 & $44 \pm 0.06$ & $31 \pm 0.03$ & $35 \pm 0$ & $22 \pm 0.14$ & $11 \pm 0.06$ & $11 \pm 0.03$ \\
\hline & & 100 & $47 \pm 0.03$ & $35 \pm 0.06$ & $37 \pm 0.03$ & $25 \pm 0.03$ & $15 \pm 0.03$ & $13 \pm 0$ \\
\hline & & 150 & $52 \pm 0.14$ & $39 \pm 0.06$ & $40 \pm 0.03$ & $27 \pm 0.06$ & $17 \pm 0.03$ & $15 \pm 0.03$ \\
\hline \multirow{3}{*}{\multicolumn{2}{|c|}{ Fluconazole }} & 50 & $11 \pm 0.06$ & $12 \pm 0$ & $13 \pm 03$ & $15 \pm 0$ & $10 \pm 0$ & $11 \pm 0$ \\
\hline & & 100 & $13 \pm 0$ & $14 \pm 0$ & $15 \pm 0.03$ & $19 \pm 0$ & $12 \pm 0.03$ & $13 \pm 0$ \\
\hline & & 150 & $18 \pm 0.14$ & $17 \pm 0$ & $19 \pm 0.03$ & $22 \pm 0.06$ & $15 \pm 0.06$ & $16 \pm 0.14$ \\
\hline \multirow{3}{*}{$\begin{array}{l}\text { AgNPs } \\
\text { Fluconazole }\end{array}$} & \multirow{3}{*}{$\&$} & 50 & $49 \pm 0.06$ & $38 \pm 0$ & $27 \pm 03$ & $19 \pm 0$ & $16 \pm 0$ & $10 \pm 0.03$ \\
\hline & & 100 & $53 \pm 0.03$ & $41 \pm 0$ & $33 \pm 0$ & $22 \pm 0$ & $18 \pm 0.06$ & $12 \pm 0$ \\
\hline & & 150 & $55 \pm 0.06$ & $44 \pm 0.03$ & $36 \pm 0$ & $24 \pm 0.06$ & $22 \pm 0.06$ & $15 \pm 0$ \\
\hline
\end{tabular}

* Mean surface area of the inhibition zone was calculated for each from the mean diameter \pm SD

$\checkmark$ Indicates significant larger inhibition zone than that of Fluconazole at $p<0.05$ significant level.

The less inhibition effects of Fluconazole $(15,17$ and $18 \mathrm{~mm})$ were against the pathogenic fungi $F$. oxysporum f. sp. lycopersici Fol4287, A. flavus Link ex Fries group and A. niger van Tiegh, respectively. However, the biosynthesized AgNPs revealed significant synergistic effects when companied with Fluconazole in addition to its antifungal activities showing higher fold areas (Table 4)

Table 4 Synergistic effect of AgNPs and Fluconazole.

\begin{tabular}{|c|c|c|c|}
\hline \multirow{2}{*}{ Fungi } & \multicolumn{2}{|c|}{ Zone of inhibition (mm, mean) $*$} & \multirow[t]{2}{*}{ Increase in fold area } \\
\hline & Fluconazole $(A)$ & AgNPs \& Fluconazole $(B)$ & \\
\hline Aspergillus niger van Tiegh & 13 & 53 & 15.62 \\
\hline A. flavus Link ex Fries group & 14 & 41 & 7.58 \\
\hline Fusarium oxysporum f. sp. lycopersici Fol4287 & 12 & 18 & 1.25 \\
\hline
\end{tabular}

*Mean surface area of the inhibition zone was calculated for each from the mean diameter.

-Increase in fold area was calculated as $(B 2-A 2) / A 2$, where A and B are the inhibition zones for Fluconazole and Fluconazole \& AgNPs, respectively.

\section{Minimal inhibitory concentration}

The biocidal action of $C$. albicans ATCC10231 growth was significantly higher at the concentrations of AgNPs 50,100 and $125 \mu \mathrm{g} / \mathrm{ml}$ than lower concentrations. Fluconazole inhibited C. albicans ATCC10231 at $125 \mu \mathrm{g} / \mathrm{ml}$ (Figure 6a). Both AgNPs and Penicillin G showed the same MIC values $(6.25 \mu \mathrm{g} / \mathrm{ml})$ against $S$. aureus ATCC25923 in addition to complete inhibition at $25 \mu \mathrm{g} / \mathrm{ml}$ (Figure $6 \mathrm{~b}$ ).

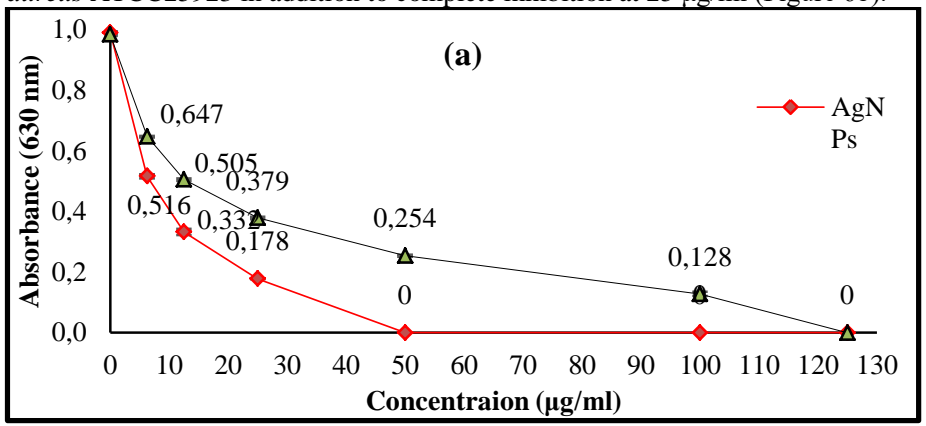

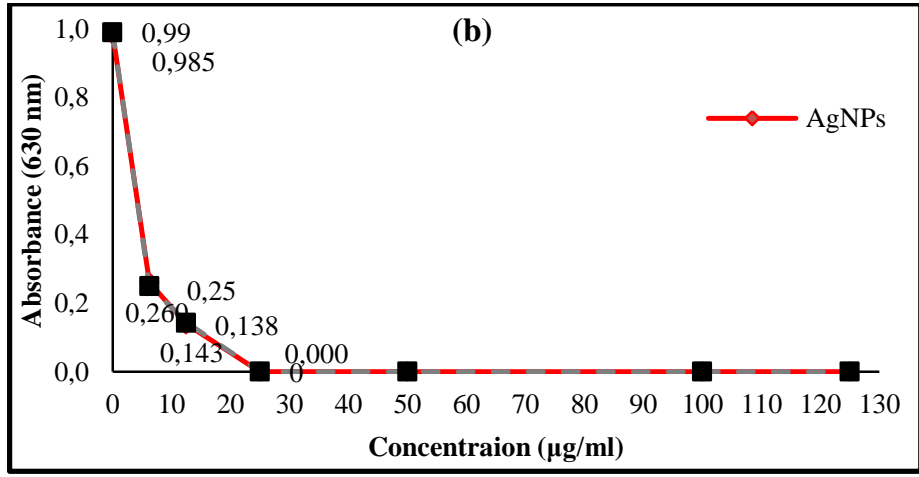

Figure 6 (a) Effect of AgNPs and Fluconazole on the growth of C. albicans ATCC10231. (b) Effect of AgNPs and Penicillin G against $S$. aureus ATCC25923. 


\section{TEM of nanosilver treated microorganisms}

Antimicrobial activities of AgNPs against $S$. aureus ATCC25923 and $F$. oxysporum f. sp. lycopersici Fol4287 were easily demonstrated by TEM analysis as shown in Figures 7 and 8. TEM micrographs showed the morphological changes of the treated S. aureus ATCC25923 cells and inhibition of cell multiplication. The treated $F$. oxysporum f. sp. lycopersici Fol4287. TEM micrographs showed many changes, including reduced size of treated cells, the formation of a mucilage matrix connecting the hyphal cells together, the appearance of big vacuole and lipid droplets with severe leakage of cytoplasmic contents.
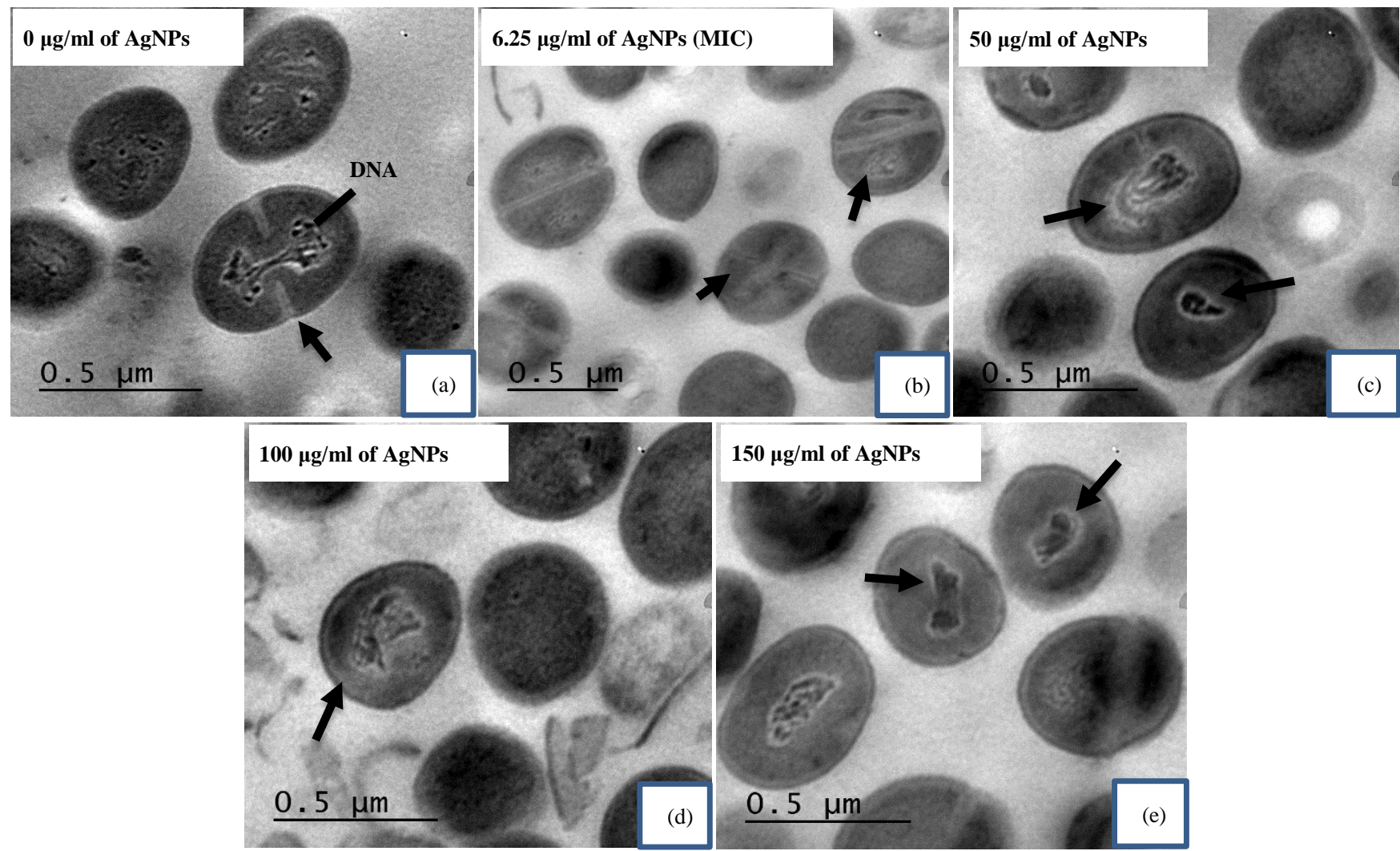

Figure 7 The bactericidal effect of AgNPs on the ultrastructure of S. aureus ATCC25923. (a) is a negative control (without nanosilver). Note normal cell division (arrow) and DNA replication. (b), (c), (d) and (e) are treated samples, there is no cell division observed at $150 \mu \mathrm{g} / \mathrm{mL}$ of AgNPs. The amount of DNA appeared to be less than those of untreated ones (arrow).

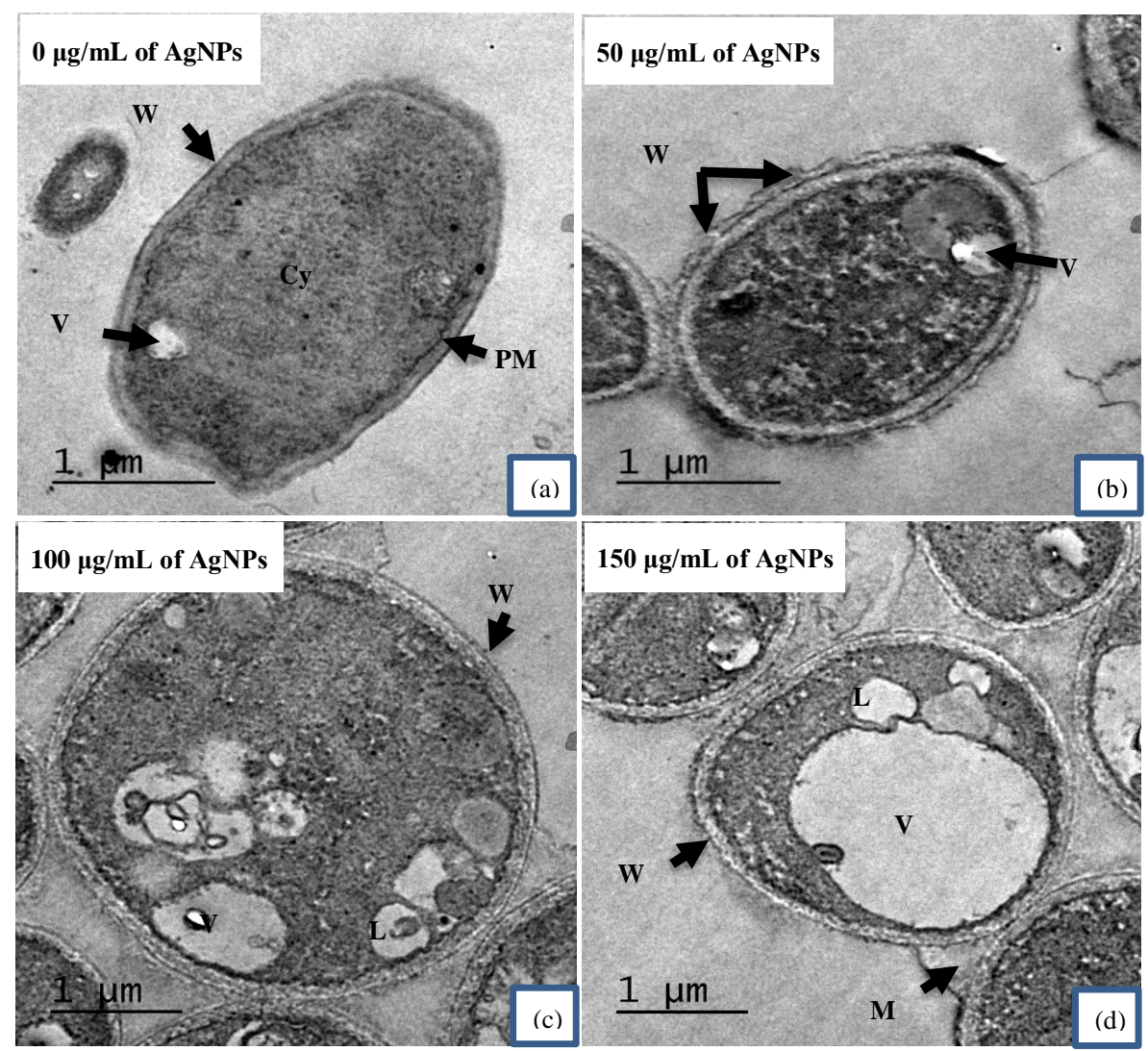

Figure 8 The antifungal activity of AgNPs on the ultrastructure of $F$. oxysporum f. sp. lycopersici Fol4287. (a) is a negative control (without nanosilver). Note normal cell wall (W), plasma membrane (PM), Vacuole (V) and compact cytoplasm (Cy). (b), (c) and (d) are treated samples, note the formation of a mucilage substance (M) connecting the hyphae together. Note also big vacuole (V) and lipid droplets (L). 


\section{DISCUSSION}

Bacteria are considered as an excellent source for the extracellular biosynthesis of nanomaterials. There is a bigwig whack to discover novel bacterial strain having motivated biological potential (Galvez et al., 2019). The crude metabolite of E. coli D8 MF06257 was used as a reducing agent, solvent typology and capping agent in the NPs extracellular biosynthesis. This type of synthesis is safe, renewable, simple, eco-friendly and cost-effective (Saifuddin et al., 2009). Thi biosynthesis was performed within 1-2 minutes at room temperature and sun light. The colour alteration into brown was due to the excitation of surface plasmon vibrations in the AgNPs (Baalousha et al., 2006). The reduction of silver ions may be resulting from the NADH dependent enzymes activity present in the crude metabolite and/or some redox agents such as sulfur-containing proteins (Krishnaraj $\boldsymbol{e t}$ al., 2012). The present study reported the ability of $E$. coli D8 to produce NR (NADH dependent enzymes) with enzyme activity 2.18 $\mu \mathrm{mol} / \mathrm{hr} / \mathrm{ml}$ while it was about $0.152 \mu \mathrm{mol} / \mathrm{hr} / \mathrm{mL}$ for $B$. subtilis as reported by Saifuddin et al. (2009). The deactivated NR of E. coli D8 metabolite (by heating) did not exhibit any synthesis of AgNPs in the dark condition, while it produced AgNPs in sunlight after 1-2 minutes indicating NR is not the only factor in the silver ion reduction. Duan $\boldsymbol{e t}$ al. (2015) suggested quinones act as an electron shuttle compound in the presence of sunlight and reduced silver ions into AgNPs. Sharma et al. (2012) believed that the crude metabolite of E. coli contains three water soluble quinones; menaquinone, demethylmenaquinone and ubiquinone.

The Spectrophotometer analysis of the plasmon absorption of the produced AgNPs showed maximum peak at $429 \mathrm{~nm}$ indicating to the good dispersion of particles in the nanocolloids as reported by Okumura et al. (2016). Stability, size and shape of nanomaterials are essential characteristics for use in biomedical applications (Pal et al., 2007). Variable conditions such as concentration of the metal ions, temperature, the incubation period, $\mathrm{pH}$ (Krishnaraj et al., 2012) and effect of the solar irradiation (Boopathi et al., 2012) were tested to form regular shaped, small sized, and stable NPs.

The optimization processes confirmed that the concentration of silver nitrate $1.5 \mathrm{mM}$ was the most suitable for AgNPs biosynthesis that was also reported by Rahimi et al. (2016) results. Studying the different levels of temperatures, $35^{\circ} \mathrm{C}$ were found to be optimum for the stable formation of $\mathrm{AgNPs}$, which matched with Shahzad et al. (2019). The $\mathrm{pH}$ of the reaction mixture greatly influenced the AgNPs formation as well as stability (Xiu et al., 2012). The best conditional $\mathrm{pH}$ value was 7.0 which perform regular and stable AgNPs biosynthesis (Gurunathan et al., 2009). The synthesis of AgNPs in the presence of solar irradiation was observed through the first minute and became over-reading at UV-Vis spectroscopy after the sixth minute. Similarly, Streptomyces sp. was used to reduce AgNO3 in solution within few minutes using sunlight (Abou-Dobara et al., 2017). The XRD pattern for AgNPs diffraction peaks confirmed the incidence of the face centered cubic (FCC) crystal structure on the crystalline AgNPs (Hu et al., 2013) which matched with the produced AgNPs by Mukherji et al. (2018). These results confirmed the synthesis of AgNPs after the reduction of AgNO3 (Li and Liu, 2010). TEM micrographs showed that the biosynthesized NPs were found to be spherical in shape with a size in the range of 6-17 nm which lies in the best class $(0-30 \mathrm{~nm})$ which matched with those obtained by Balakumaran et al. (2016) and El-Naggar et al. (2016). Also, Gopinath and Velusamy (2013) used Bacillus sp. GP-23 as spherical NPs with size in the range of 7-21 nm producers. In addition, the produced AgNPs has a negative charge (-33.6) which matched with Bacillus sp. AgNPs, that reported by Elbeshehy et al. (2015).

The aggregation of NPs is considered as a common problem which decreases their biological potential. The outer capping agents determine the size and morphology of NPs by preventing their aggregation (Duan et al., 2015). The biosynthesized AgNPs from E. coli D8 crude metabolite were uniform and monodispersed in size as well as stable for more than 6 months without aggregation at room temperature compared to Trichoderma longibrachiatum AgNPs that produced by Elamawi et al. (2018). The FTIR spectrum confirmed the presence of proteins associated with E. coli D8 AgNPs, which might act as a capping and stabilizing agent. Moreover, the negative charge of AgNPs might increase the repulsion force between particles which minimize their aggregation (Siddique et al., 2013).

The biosynthesized AgNPs by the crude metabolite of E. coli D8 exhibited some potent inhibitory activities against all the pathogenic strains. The highest antibacterial activity of AgNPs by E. coli D8 crude metabolite was recorded against $S$. aureus ATCC25923 followed by E. coli ATCC25922, multi-drug resistant $P$. aeruginosa ATCC27853, K. pneumoniae ATCC33495 and B. cereus ATCC6633. Generally, the previous antimicrobial activities were more competitive to AgNPs produced by B. licheniformis (Gomaa, 2017) and matched with the antimicrobial activity of $S$. viridodiastaticus AgNPs (Mohamedin et al. 2015).

The biosynthesized AgNPs by the crude metabolite of E. coli D8 exhibited some potent inhibitory activities against all the pathogenic strains. Furthermore, the antifungal activity of AgNPs exhibited a great interest as E. coli D8 AgNPs showed a significant antifungal activity against $C$. albicans ATCC10231. Balakumaran et al. (2016) AgNPs produced by A. terreus inhibited the growth of $C$. albicans with a proximate activity. In addition, E. coli D8 AgNPs possessed a superior potent toxic effect against $A$. niger followed by $A$. fumigatus, A. flavus, $A$. alternata and $F$. oxysporum f. sp. lycopersici. Similarly, the biosynthesized AgNPs by Streptomyces sp. VITSTK7 showed anti-Aspergillus activity agains A. niger, A. flavus and A. fumigatus with antifungal index in the range of $62-75 \%$ (Thenmozhi et al., 2013). The AgNPs of E. coli D8 showed a significan antifungal activity against $F$. oxysporum f. sp. lycopersici that matched with AgNPs, produced by Cryphonectria sp. (Dar et al., 2013). In contrast, the mycelial growth of plant pathogenic A. alternata was less inhibited by E. coli D8 AgNPs than AgNPs produced by A. solani F10 (Abdel-Hafez et al., 2016).

E. coli D8 AgNPs increased the antifungal activity of the Fluconazole and increased diameters of ZOI. This synergistic effect was revealed increases in the fold areas especially against $A$. niger, A. flavus and $F$. oxysporum f. sp. lycopersici. Gajbhiye et al. (2009) reported that the combination between Fluconazole and AgNPs increased ZOI and fold areas against Phoma glomerata, $P$. herbarum, F. semitectum, Trichoderma sp. and C. albicans. It was thought that the synergistic effect may be due to formation of AgNP-Fluconazole complex by chelating that lead to more serious damage to microbe's cells (Fayaz et al., 2010). Antimicrobial potential depended on the dose and it increased by increasing the concentration. The MIC values for $S$. aureus ATCC25923 and C. albicans ATCC10231 were $6.25 \mu \mathrm{g} / \mathrm{ml}$ and $50 \mu \mathrm{g} / \mathrm{ml}$, respectively. Paul et al. (2018) reported the MIC values for different Candida species against curcumin-AgNPs ranged from $31.2 \mu \mathrm{g} / \mathrm{ml}$ to $250 \mu \mathrm{g} / \mathrm{ml}$. AgNPs of Pilimelia columellifera subsp pallida SL19 strain inhibited $C$. albicans at concentration equal to $64 \mu \mathrm{g} / \mathrm{ml}$ as reported by Wypij et al. (2017). The MIC of the biosynthesized AgNPs against S. aureus was found to be $2 \mu \mathrm{g} / \mathrm{ml}$ as reported by Yuan et al. (2017) and Wady et al. (2014). Regarding antimicrobial activity, there are various hypothetical mechanisms of the action of AgNPs on microbes' cells, such as interacting with the cell wall leading to cell burst (Radzig et al., 2013). Both S. aureus ATCC25923 and $F$. oxysporum f. sp. lycopersici Fol4287 changed in response to their treatment with AgNPs which were easily trapped and absorbed through cell membranes. The changes included inhibition of $S$. aureus ATCC25923 multiplication in addition to having a low amount of DNA. The untreated hyphal cells of $F$. oxysporum f. sp. lycopersici Fol4287 showed a normal cell wall compact cytoplasm, cell membrane and small vacuole. On the other hand, many changes were observed after the treatment by AgNPs such as the formation of a mucilage matrix connecting the hyphal cells together, the appearance of big vacuole and lipid droplets. The accumulating of AgNPs in cytoplasmic membrane and cytoplasm may be the main factor in the major morphological changes in addition to the accumulation in the cell nucleus (Abdel-Hafez et al , 2016). This accumulation may be indicated to the interaction of AgNPs with DNA (Vahdati and Sadeghi, 2013). In addition, the smallest AgNPs can penetrate the cell membranes and interact with their proteins (including thiol groups in enzymes) leading to blocking, inactivation and cell death (Radzig et al., 2013).

\section{CONCLUSIONS}

Escherichia coli D8 (MF062579) crude metabolite was able to synthesize AgNPs within 1-2 minutes in a green and cost-effective method. The presence of protein was confirmed and could be acted as stabilizing and capping agents. This method provides AgNPs possessing competitive size, shape and antimicrobial action beside to synergy potential with Fluconazole against $A$. niger van Tiegh, A. flavus Link ex Fries group and $F$. oxysporum f. sp. lycopersici Fol4287. Thusly, E. coli could be developed as a nano-biofactory against pathogenic microbes having severe damage effects on their DNA structure.

\section{REFERENCES}

Abdel-Hafez SI, Nafady NA, Abdel-Rahim IR, Shaltout AM, Daròs JA and Mohamed MA. 2016. Assessment of protein silver nanoparticles toxicity against pathogenic Alternaria solani. 3 Biotech, 6: 199-210. https://doi.org/10.1007/s13205-016-0515-6

Abou-Dobara, MI, El-Sayed, AKA and Omar, NF. 2017. Streptomyces violaceoruber ES: A producer of bioprospective metabolite for rapid and green synthesis of antibacterial silver nanoparticles. Egypt $J$ Bot, 57: 31-43 https://doi.org/10.21608/ejbo.2017.1017.1089

Annamalai J and Nallamuthu T. 2016. Green synthesis of silver nanoparticles: characterization and determination of antibacterial potency. Appl Nanosci, 6 259-265. https://doi.org/10.1007/s13204-015-0426-6

Baalousha M, Kammer FVd, Motelica-Heino M, Baborowski M, Hofmeister C and Le Coustumer P. 2006. Size-based speciation of natural colloidal particles by flow field flow fractionation, inductively coupled plasma-mass spectroscopy and transmission electron microscopy/X-ray energy dispersive spectroscopy: Colloids-trace element interaction. Environ Sci Technol, 40: 2156-2162. https://doi.org/10.1021/es051498d

Balakumaran MD, Ramachandran R, Balashanmugam P, Mukeshkumar DJ and Kalaichelvan PT. 2016. Mycosynthesis of silver and gold nanoparticles: Optimization, characterization and antimicrobial activity against human

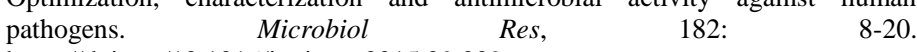
https://doi.org/10.1016/j.micres.2015.09.009 
Birla SS, Tiwari VV, Gade AK, Ingle AP, Yadav AP and Rai M. 2009. Fabrication of silver nanoparticles by Phoma glomerata and its combined effect against Escherichia coli, Pseudomonas aeruginosa and Staphylococcus aureus. Lett Appl Microbiol, 48: 173-179. https://doi.org/10.1111/j.1472 765X.2008.02510.X

Bocate KP, Reis GF, de Souza PC, Junior AG, Durán N, Nakazato G, Furlaneto MC, de Almeida RS and Panagio LA. 2019. Antifungal activity of silver nanoparticles and simvastatin against toxigenic species of Aspergillus. Int J Food Microbiol, 291:79-86. https://doi.org/10.1016/j.ijfoodmicro.2018.11.012

Boopathi S, Gopinath S, Boopathi T, Balamurugan V, Rajeshkumar R and Sundararaman M. 2012. Characterization and antimicrobial properties of silver and silver oxide nanoparticles synthesized by cell-free extract of a mangroveassociated Pseudomonas aeruginosa M6 using two different thermal treatments. Ind Eng Chem Res, 51: 5976-5985. https://doi.org/10.1021/ie3001869

Clinical and Laboratory Standards document M2-A9. 2006. Performance standards for antimicrobial disk susceptibility tests: Approved standard- Ninth Edition, Clinical and Laboratory Standards Institute, Wayne, Pennsylvania, USA. Clinical Laboratory Standards document M27-A3. 2008. Reference method for broth dilution antifungal susceptibility testing of yeasts: Approved StandardThird Edition, Clinical and Laboratory Standards Institute, Wayne, Pennsylvania, USA.

Clinical and Laboratory Standards document M100-S26. 2017. Performance standards for antimicrobial susceptibility testing: Approved standard- twentyseven Edition, Clinical and Laboratory Standards Institute, Wayne, Pennsylvania, USA.

Dar MA, Ingle A and Rai, M. 2013. Enhanced antimicrobial activity of silver nanoparticles synthesized by Cryphonectria sp. evaluated singly and in combination with antibiotics. Nanomedicine, 9: 105-110. https://doi.org/10.1016/j.nano.2012.04.007

De Souza TA, Souza LR and Franchi LP. 2019. Silver nanoparticles: An integrated view of green synthesis methods, transformation in the environment and toxicity. Ecotoxicol Environ Saf, 171: 691-700. https://doi.org/10.1016/j.ecoenv.2018.12.095

Duan H, Wang D. and Li Y. 2015. Green chemistry for nanoparticle synthesis Chem Soc Rev, 44: 5778-5792. https://doi.org/10.1039/C4CS00363B

Elamawi RM, Al-Harbi RE and Hendi AA. 2018. Biosynthesis and characterization of silver nanoparticles using Trichoderma longibrachiatum and their effect on phytopathogenic fungi. Egypt J Biol Pest Control, 28: 1-11. https://doi.org/10.1186/s41938-018-0028-1

Elbeshehy EK, Elazzazy AM and Aggelis G. 2015. Silver nanoparticles synthesis mediated by new isolates of Bacillus spp., nanoparticle characterization and their activity against Bean Yellow Mosaic Virus and human pathogens. Front Microbiol, 6: 453-453. https://doi.org/10.3389/fmicb.2015.00453

El-Naggar NEA, Mohamedin A, Hamza SS and Sherief AD. 2016. Extracellular biofabrication, characterization, and antimicrobial efficacy of silver nanoparticles loaded on cotton fabrics using newly isolated Streptomyces sp. SSHH-1E. J Nanomater, 2016: 3257359. https://doi.org/10.1155/2016/3257359

Fayaz AM, Balaji K, Girilal M, Yadav R, Kalaichelvan PT and Venketesan R. 2010. Biogenic synthesis of silver nanoparticles and their synergistic effect with antibiotics: A study against gram-positive and gram-negative bacteria Nanomedicine, 6: 103-109. https://doi.org/10.1016/j.nano.2009.04.006

Gajbhiye M, Kesharwani J, Ingle A, Gade A and Rai M. 2009. Fungus-mediated synthesis of silver nanoparticles and their activity against pathogenic fungi in combination with fluconazole. Nanomedicine, 5: 382-386 https://doi.org/10.1016/j.nano.2009.06.005

Galvez AM, Ramos KM, Teja AJ and Baculi R. 2019. Bacteria exopolysaccharide-mediated synthesis of silver nanoparticles and their application on bacterial biofilms. J Microbiol Biotechnol Food Sci, 8: 970-978. https://doi.org/10.15414/jmbfs.2019.8.4.970-978

Gomaa EZ. 2017. Silver nanoparticles as an antimicrobial agent: A case study on Staphylococcus aureus and Escherichia coli as models for Gram-positive and Gram-negative bacteria. J Gen Appl Microbiol, 63: 3643. https://doi.org/10.2323/jgam.2016.07.004

Gopinath V and Velusamy P. 2013 Extracellular biosynthesis of silver nanoparticles using Bacillus sp. GP-23 and evaluation of their antifungal activity towards Fusarium oxysporum. Spectrochim Acta A Mol Biomol Spectrosc, 106 170-174. https://doi.org/10.1016/j.saa.2012.12.087

Gurunathan S, Kalishwaralal K, Vaidyanathan R, Venkataraman D, Pandian SRK, Muniyandi J and Eom SH. 2009. Biosynthesis, purification and characterization of silver nanoparticles using Escherichia coli. Colloids Surf B, 74: 328-335. https://doi.org/10.1016/j.colsurfb.2009.07.048

Hamidi A, Yazdi ME, Amiri MS, Hosseini HA and Darroudi M. 2019. Biologica synthesis of silver nanoparticles in Tribulus terrestris L. extract and evaluation of their photocatalyst, antibacterial, and cytotoxicity effects. Res Chem Intermed, 1 : 1-11. https://doi.org/10.1007/s11164-019-03770-y

Hanaor D, Michelazzi M, Leonelli C and Sorrell CC. 2012. The effects of carboxylic acids on the aqueous dispersion and electrophoretic deposition of

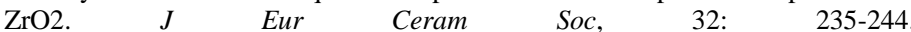
https://doi.org/10.1016/j.jeurceramsoc.2011.08.015
Harley SM. 1993. Use of a simple, colorimetric assay to demonstrate conditions for induction of nitrate reductase in plants. Am Biol Teach, 55: 161-164. https://doi.org/10.2307/4449615

He S, Guo Z, Zhang Y, Zhang S, Wang J and Gu N. 2007. Biosynthesis of gold nanoparticles using the bacteria Rhodopseudomonas capsulate. Mater Lett, 61: 3984-3987. https://doi.org/10.1016/j.matlet.2007.01.018

Hu C, Liu Y, Qin J, Nie G, Lei B, Xiao Y and Rong J. 2013. Fabrication of reduced graphene oxide and sliver nanoparticle hybrids for Raman detection of absorbed folic acid: a potential cancer diagnostic probe. ACS Appl Mater Interfaces, 5: 4760-4768. https://doi.org/10.1021/am4000485

Imhoff JF. 2005. "Enterobacteriales". In: Brenner DJ, Krieg NR and Staley JR. (eds). 2005. Bergey's Manual® of Systematic Bacteriology: Volume Two: The Proteobacteria. Springer Science \& Business Media. pp. 587-850 Springer, Boston, MA, USA. https://doi.org/10.1007/0-387-28022-7_13

Krishnaraj C, Ramachandran R, Mohan K and Kalaichelvan PT. 2012. Optimization for rapid synthesis of silver nanoparticles and its effect on phytopathogenic fungi. Spectrochim Acta A Mol Biomol Spectrosc, 93: 95-99. https://doi.org/10.1016/j.saa.2012.03.002

Li J and Liu CY. 2010. Ag/graphene heterostructures: synthesis, characterization and optical properties. Eur J Inorg Chem, 2010: 1244-1248. https://doi.org/10.1002/ejic.200901048

Mohamedin A, El-Naggar NEA, Shawqi Hamza S and Sherief AA. 2015. Green synthesis, characterization and antimicrobial activities of silver nanoparticles by Streptomyces viridodiastaticus SSHH-1 as a living nanofactory: statistical optimization of process variables. Curr Nanosci, 11: 640-654. https://doi.org/10.2174/1573413711666150309233939

Mukherji S, Bharti S, Shukla G and Mukherji S. 2018. Synthesis and characterization of size-and shape-controlled silver nanoparticles. Phys Sci Rev, 4: 20170082. https://doi.org/10.1515/psr-2017-0082

Okumura A, Saito K and Tatsuma T. 2016. Asymmetric optical properties of photocatalytically deposited plasmonic silver nanoparticles. Phys Chem Phys 18:7007-7010. https://doi.org/10.1039/C6CP00331A

Pal JS, Giorgi F, Bi X, Elguindi N, Solmon F, Gao X, Rauscher SA, Francisco R, Zakey A, Winter J, Ashfaq M, Syed FS, Bell JL, Diffenbaugh N, Karmacharya J Konaré A, Martinez D, da Rocha RP, Sloan LC and Steiner AL. 2007. Regional climate modeling for the developing world: the ICTP RegCM3 and RegCNET Bull Am Meteor Soc, 88: 1395-1409. https://doi.org/10.1175/BAMS-88-9-1395

Paul S, Mohanram K and Kannan I. 2018. Antifungal activity of curcumin-silver nanoparticles against fluconazole-resistant clinical isolates of Candida species $A Y U$, 39: 182-186. https://doi.org/10.4103/ayu.AYU 2418

Paul, M. and Londhe, V.Y. (2019). "Pongamia pinnata seed extract-mediated green synthesis of silver nanoparticles: Preparation, formulation and evaluation of bactericidal and wound healing potential." Appl Organomet Chem 3: e4624, https://onlinelibrary.wiley.com/doi/full/10.1002/aoc.4624 (Nov. 29,2018) https://doi.org/10.1002/aoc.4624

Quinteros MA, Aiassa Martínez IM, Dalmasso PR and Páez PL. 2016. Silver nanoparticles: biosynthesis using an ATCC reference strain of Pseudomonas aeruginosa and activity as broad spectrum clinical antibacterial agents. Int $J$ Biomater, 2016: 1-7. http://dx.doi.org/10.1155/2016/5971047

Radzig MA, Nadtochenko VA, Koksharova OA, Kiwi J, Lipasova V and Khmel IA. 2013. Antibacterial effects of silver nanoparticles on gram-negative bacteria Influence on the growth and biofilms formation, mechanisms of actions. Colloids
Surf
$B$
Biointerfaces,
102 :
300-306

https://doi.org/10.1016/j.colsurfb.2012.07.039

Ruud CO, Barrett CS, Russell PA and Clark RL. 1976. Selected area electron diffraction and energy dispersive X-ray analysis for the identification of asbestos fibres, a comparison. Micron, 7: 115-132. https://doi.org/10.1016/00477206(76)90055-8

Saifuddin N, Wong CW and Yasumira AA. 2009. Rapid biosynthesis of silver nanoparticles using culture supernatant of bacteria with microwave irradiation. $J$ Chem, 6: 61-70. http://dx.doi.org/10.1155/2009/734264

Shahverdi AR, Minaeian S, Shahverdi HR, Jamalifar H and Nohi AA. 2007. Rapid synthesis of silver nanoparticles using culture supernatants of Enterobacteria: a novel biological approach. Process Biochem, 42: 919-923. https://doi.org/10.1016/j.procbio.2007.02.005

Shahzad A, Saeed H, Iqtedar M, Hussain SZ, Kaleem A, Abdullah R and Chaudhary A. 2019. Size-Controlled Production of Silver Nanoparticles by Aspergillus fumigatus BTCB10: Likely Antibacterial and Cytotoxic Effects. $J$ Nanomater, 2019: 1-14. https://doi.org/10.1155/2019/5168698

Sharma P, de Mattos MJ, Hellingwerf KJ and Bekker M. 2012. On the function of the various quinone species in Escherichia coli. FEBS J, 279: 3364-3373. https://doi.org/10.1111/j.1742-4658.2012.08608.x

Siddique, Y.H., Fatima, A., Jyoti, S., Naz, F., Khan, W., Singh, B.R. and Naqvi, A.H. (2013). "Evaluation of the toxic potential of graphene copper nanocomposite (GCNC) in the third instar larvae of transgenic Drosophila melanogaster (hsp70-lacZ) Bg9." PloS one 8: 880944 https://journals.plos.org/plosone/article?id=10.1371/journal.pone.0080944 (Dec $5,2013)$ 
Sondi I and Salopek-Sondi B. 2004. Silver nanoparticles as antimicrobial agent: a case study on $E$. coli as a model for Gram-negative bacteria. $J$ Colloid Interface Sci, 275: 177-182. https://doi.org/10.1016/j.jcis.2004.02.012

Sumitha S, Vasanthi S, Shalini S, Chinni SV, Gopinath SC, Kathiresan S, Anbu P and Ravichandran V. 2019. Durio zibethinus rind extract mediated green synthesis of silver nanoparticles: Characterization and biomedical applications. Pharmacogn Mag, 15: 52-58. https://doi.org/10.4103/pm.pm 400 18

Thenmozhi M, Kannabiran K, Kumar R and Khanna VG. 2013. Antifungal activity of Streptomyces sp. VITSTK7 and its synthesized Ag2O/Ag nanoparticles against medically important Aspergillus pathogens. J Mycol Med, 23: 97-103. https://doi.org/10.1016/j.mycmed.2013.04.005

Vahdati AR and Sadeghi B. 2013. A study on the assessment of DNA strandbreaking activity by silver and silica nanoparticles. J Nanostruct Chem, 1: 1-3. https://doi.org/10.1186/2193-8865-3-7

Wady AF, Machado AL, Foggi CC, Zamperini CA, Zucolotto V, Moffa EB and Vergani CE. 2014. Effect of a Silver Nanoparticles Solution on Staphylococcus aureus and Candida spp. J Nanomater, 2014: 128-135. https://doi.org/10.1155/2014/545279

Wang RL, Li DP, Wang LJ, Zhang X, Zhou ZY, Mu JL and Su ZM. 2019. The preparation of new covalent organic framework embedded with silver nanoparticles and its applications in degradation of organic pollutants from waste water. Dalton Trans, 48: 1051-1059. https://doi.org/10.1039/C8DT04458A

Wypij M, Czarnecka J, Dahm H, Rai M and Golinska P. 2017. Silver nanoparticles from Pilimelia columellifera subsp. pallida SL19 strain demonstrated antifungal activity against fungi causing superficial mycoses. $J$ Basic Microbiol, 57: 793-800. https://doi.org/10.1002/jobm.201700121

Xiu ZM, Zhang QB, Puppala HL, Colvin VL and Alvarez PJ. 2012. Negligible particle-specific antibacterial activity of silver nanoparticles. Nano Lett, 12: 4271-4275. https://doi.org/10.1021/nl301934w

Yuan YG, Peng QL and Gurunathan S. 2017. Effects of silver nanoparticles on multiple drug-resistant strains of Staphylococcus aureus and Pseudomonas aeruginosa from mastitis-infected goats: an alternative approach for antimicrobial therapy. Int $J$ Mol Sci, 18: 569-589. https://doi.org/10.3390/ijms18030569 